\section{Lost in the Stacks for Forty-One Years}

\section{Robert Lopresti}

recently retired after more than four decades as a librarian.

My job title always included "Government Documents" or "Government Information," although, as I am sure you understand, a large share of my time was dedicated to what is covered by that familiar phrase "other duties as assigned."

But having turned in my keys and name tag gave me a chance to ponder the high (and low) lights of my career. Here are a few of the more memorable moments related to the govdoc biz.

\section{\#}

My first job was at a public library. It was the biggest in our part of the county and when one of the small libraries had a reference question they couldn't answer they bounced it to us. One of those smaller institutions had a director named Miss D. Her main characteristic, as far as I could tell, was that she was terrified of the members of her library board.

One day she called up and asked for the government documents librarian. It seemed one of her board members was looking for some federal statistics about drug abuse.

I wrote the questions down. "Some of these I can answer," I told her. "But in some cases I don't think the data is available."

"Well, do what you can."

I did. This was long before the Internet so I had to dig through a whole lot of books. Finally, after several hours of toil I called her up.

"I was able to find most of your answers, but not all of them."

"Oh," she said. "Then never mind." And hung up.

\#

My next job was at a college library. One night a college student came up to the reference desk and asked: "Is Nicaragua in Europe?" This was during the Reagan administration when it looked like we might be invading that country any day.

I think I kept a straight face. "No, Nicaragua is in Central America."

"Oh," she said. "Is Central America in Europe?"

\#

My third professional job was at a university. One day an older community member wandered into my department.

"So you get federal documents here."

"That's right."

"Do you have classified publications?"
I laughed. "I can barely get them to send us tax forms." \#

But let's talk about something they did send us. One day my assistant placed a newly arrived publication on my desk, as opposed to the usual location.

I figured out why pretty quickly. At the bottom of the cover it said: FOR LAW ENFORCEMENT USE ONLY. Of course, that is one category of publication that is not supposed to be sent to depositories.

The pamphlet was about an organization that does not approve of certain activities and allegedly had a habit of blowing up buildings in which those activities took place. This publication explained to law enforcement officials the methods these people had been using.

This was before email so I phoned the GPO. "You didn't mean to send us that publication."

"Why not?"

"Because it's full of diagrams of explosive devices. It's basically a manual for bomb-makers."

"We'll get back to you."

Later that day they did. "You're right. Destroy it."

So, of course I did.

A few days later I got a letter from GPO, addressed to all depository libraries. It said that the publication was sent by mistake and we should return it immediately.

I picked up the phone. "You told me to destroy it. How am I supposed to return it?"

"We'll get back to you." it."

They did. "Send us a letter explaining how you destroyed

I was sorely tempted to say, "I used the method shown on page seven.” But who needs that kind of trouble?

I supervised the shifting of 200,000 government publications at least five times. On the day we finished one move we had the windows open and a squirrel hopped in. He scampered straight to the A 13's, which are, of course, the publications of the Forest Service.

"Boy," I thought, "if only the students could find their way as easily as you!"

A student had been asked to find out everything she could about someone-anyone-who lived in our county in 1880. I took her to the microfilm reels for the 1880 census, showed her how to use them and went back to my desk.

Soon she reappeared with a question: "What's a demimonde?" 


\section{Lost in the Stacks for Forty-One Years}

I knew the answer but following the old rule I took her to a dictionary to check that it indeed meant prostitute.

She had found an entire building full of demimondes: a brothel. She was thrilled.

I told this to another librarian who nodded gravely. "In Seattle they called them seamstresses."

\#

One of our regular patrons was a Vietnam vet who was having trouble with the Department of Veterans Affairs (VA). As he told the story he wanted to receive disability payments because his time over there had driven him crazy. The VA's defense was —again, according to him — that he was already crazy when the army drafted him. Not a great argument.

A member of the public is welcome to use our collection and anyone can borrow our federal publications, if they show ID. This veteran wanted to borrow some but he refused to show his ID because he thought the VA might be tracking what books he read.

I told him that didn't match my experience of reality but I respected his right to his own. Nonetheless, he couldn't borrow the documents.

He used them in-house, over several years. I don't know how his case turned out but he started taking better care of himself and bringing in fellow vets whom he helped use the docs. I counted that as a win.

\section{\#}

In 2006 someone stole more than six hundred pages out of our old Congressional Serial Set volumes. After more than a year and a half of sleuthing by various people at our university the thief was sent to prison.

The craziest part was that we had identified the thief within a month (he was selling our stuff on eBay). Then we had to gather evidence. But after that it took more than a year to find a law enforcement agency willing and able to cooperate. One agency told us, "We don't work on crimes with only one victim." When the Department of Homeland Security (DHS) eventually raided the man's property, they found books from more than one hundred libraries. One victim, my foot.

(Why DHS? Because he was selling across the border, which made it an Immigration and Customs Enforcement issue.)

\section{\#}

When I use a statistics compendium I try to find time to skim the introduction. That's where they hide the weird stuff: the results that don't make sense and otherwise show up, at best, only in the footnotes at the bottom of the statistics tables.

So, one day I picked up the book on occupations from the 1920 Census and found that the introduction had a section titled "Peculiar Occupations for Women." It explained that census takers had reported women in a lot of occupations that women obviously could not have been working in, like masons and plasterers. And so, the census bosses explained solemnly, the records were carefully examined and if they could figure out what the mistake was they corrected it. Or should I say if they figured out what the "mistake" was they "corrected" it. And how many female pioneers in their fields were erased from history?

That led to me writing When Women Didn't Count: The Chronic Mismeasure and Marginalization of American Women in Federal Statistics. Writing that book-and winning GODORT's Margaret T. Lane/Virginia F. Saunders Memorial Research Award for it-seemed like a great way to end my career in Gov Docs Land.

Best wishes to all of you carrying the torch forward. I will be cheering from the sidelines.

Robert Lopresti (rob@roblopresti.com), Bellingham, Washington. 